\title{
Piper betle extracts exhibit antitumor activity by augmenting antioxidant potential
}

\author{
BADRUL ALAM $^{1,2}$, RAJIB MAJUMDER $^{2}$, SHAHINA AKTER $^{2}$ and SANG-HAN LEE ${ }^{1,3}$ \\ ${ }^{1}$ Department of Food Science and Biotechnology, Kyungpook National University, Daegu 702-701, Republic of Korea; \\ ${ }^{2}$ Department of Pharmacy, Atish Dipankar University of Science and Technology, Dhaka 1213, Bangladesh; \\ ${ }^{3}$ Food and Bio-Industry Research Institute, Kyungpook National University, Daegu 702-701, Republic of Korea
}

Received March 6, 2014; Accepted September 26, 2014

DOI: $10.3892 / 01.2014 .2738$

\begin{abstract}
The present study was conducted to evaluate the methanolic extract of Piper betle leaves (MPBL) and its organic fractions with regard to antitumor activity against Ehrlich ascites carcinoma (EAC) in Swiss albino mice and to confirm their antioxidant activities. At $24 \mathrm{~h}$ post-intraperitoneal inoculation of tumor cells into mice, extracts were administered at 25, 50 and $100 \mathrm{mg} / \mathrm{kg}$ body weight for nine consecutive days. The antitumor effects of the extracts were then assessed according to tumor volume, packed cell count, viable and non-viable tumor cell count, median survival time and increase in life span of EAC-bearing mice. Next, hematological profiles and serum biochemical parameters were calculated, and antioxidant properties were assessed by estimating lipid peroxidation, reduced glutathione (GSH), superoxide dismutase (SOD) and catalase (CAT) levels. MPBL and the ethylacetate fraction (EPBL) at a dose of $100 \mathrm{mg} / \mathrm{kg}$ induced a significant decrease in tumor volume, packed cell volume and viable cell count and increased the life span of the EAC-bearing mice $(\mathrm{P}<0.05)$. Hematological and serum biochemical profiles were restored to normal levels in the extract-treated mice compared with the EAC control mice. MPBL and EPBL treatment significantly decreased lipid peroxidation $(\mathrm{P}<0.05)$ and restored GSH, SOD and CAT levels towards normal compared with the EAC control. Taken together, the results of the present study demonstrated that Piper betle extracts exhibit significant antitumor activity, which may be attributed to the augmentation of endogenous antioxidant potential.
\end{abstract}

\section{Introduction}

Free radicals [reactive oxygen species (ROS) and reactive nitrogen species] are products of normal cellular metabolism, and are extremely reactive and potentially damaging transient

Correspondence to: Dr Sang-Han Lee, Department of Food Science and Biotechnology, Kyungpook National University, 80 Daehakro, Daegu 702-701, Republic of Korea

E-mail: sang@knu.ac.kr

Key words: antitumor, antioxidant, Ehrlich ascites carcinoma, Piper betle chemical species. Numerous endogenous metabolic processes involving redox enzymes and bioenergetic electron transfer generate free radicals, which aid in the conversion of normal cells to cancerous cells (1). ROS are able to affect a number of significant biological molecules, including DNA, proteins and lipids, leading to a number of degenerative diseases, including cancer, Alzheimer's disease, arthritis and ischemic reperfusion (2). The oxidative damage to DNA may be reduced by antioxidant-rich diets, thus preventing the onset of carcinogenesis (3). In addition, the increasing incidence of cancer and the lack of anticancer drugs has resulted in the pharmacological and chemical investigation of anticancer agents obtained from medicinal plants. At present, $>100$ novel products obtained from natural sources are in clinical development, particularly as anticancer agents and anti-infectives (4).

Betelvine (Piper betle) belongs to the Piperaceae family, which is regarded as a medicinal plant in Southeast Asia. The leaves of Piper betle have been found to exhibit wound healing (5), hepatoprotective (6), antioxidant and antifertility effects, as well as antimotility effects on washed human spermatozoa (7). The primary constituent of the leaves is a volatile oil that contains phenols, betel-phenol, chavibetol, chavicol, cadinene and hydroxychavicol, which have been found to exhibit antioxidant and anticarcinogenic activities (8-10). In Bangladesh, the tribal population and aborigines chew these leaves as a narcotic, which causes fainting, profuse sweating and provides body warmth during winter (7).

The present study was performed to evaluate the antioxidant and antitumor activity of the methanolic extract of Piper betle leaves (MPBL) and its organic soluble fractions against Ehrlich ascites carcinoma (EAC) in mice.

\section{Material and methods}

Plant materials. The leaves of Piper betle L. were collected from Jahangirnagar University campus, (Dhaka, Bangladesh) in February 2012. The plant material was taxonomically identified by the National Herbarium of Bangladesh (Dhaka, Bangladesh) and recorded as voucher specimen no. JU/3334 for future reference.

Chemicals. Bovine serum albumin and bleomycin were obtained from Sigma-Aldrich (St. Louis, MO, USA). 
Trichloroacetic acid was acquired from Merck (Mumbai, India), and thiobarbituric acid (TBA) and nitroblue tetrazolium chloride were purchased from Loba Chemie Pvt. Ltd., (Mumbai, India). 5,5'-Dithiobis(-2-nitro benzoic acid), phenazonium methosulfate, nicotinamide adenine dinucleotide and reduced glutathione (GSH) were purchased from Sisco Research Laboratories Pvt., Ltd., (Mumbai, India). All other chemicals and reagents used were of the highest analytical grade.

Preparation of plant extract. The plant material was shade-dried with occasional shifting and then ground to a powder using a mechanical grinder, passed through a \#40 sieve (mesh size, $0.425 \mu \mathrm{m}$ ) and stored in an air-tight container. A total of $1.0 \mathrm{~kg}$ of dried powder material was refluxed with $\mathrm{MeOH}$ for $3 \mathrm{~h}$, then the total filtrate was concentrated until dry in vacuo at $40^{\circ} \mathrm{C}$ to render the $\mathrm{MeOH}$ extract $(240.0 \mathrm{~g})$. The extract was subsequently suspended in $\mathrm{dH}_{2} \mathrm{O}$ and successively partitioned with chloroform $\left(\mathrm{CHCl}_{3}\right)$ and ethylacetate (EtOAc) to supply the $\mathrm{CHCl}_{3}(90.0 \mathrm{~g})$ and EtOAc $(50.0 \mathrm{~g})$ fractions, respectively, and the $\mathrm{H}_{2} \mathrm{O}$ residue $(100.0 \mathrm{~g}$ ).

Animals. A total of 121 female, 6-7 week-old, Swiss albino mice (weight range, 25-30 g) were used to assess biological activity. The animals were maintained under standard laboratory conditions and had access to food and water ad libitum. The animals were acclimatized to the environment for seven days prior to the experimental procedures. All animal experiments were performed in accordance with the guidelines of the Institutional Animal Ethics Committee of Atish Dipankar University of Science and Technology, Dhaka, Bangladesh. Animal treatment and maintenance for acute toxicity and anticancer effects were conducted in accordance with the Principle of Laboratory Animal Care (NIH publication No. 85-23, revised 1985) and the Animal Care and Use Guidelines of Atish Dipankar University of Science and Technology.

Acute toxicity study. An acute oral toxicity assay was performed using healthy, non-pregnant, adult female, Swiss albino mice (weight range, 25-30 g) divided into six different groups. Increasing oral doses of MPBL (50, 100, 200, 500 and $1,000 \mathrm{mg} / \mathrm{kg}$ body weight) in distilled water were administered at $20 \mathrm{ml} / \mathrm{kg}$ to the different test groups. The normal group received distilled water only. Following treatment, the mice were allowed to feed ad libitum and observed for $48 \mathrm{~h}$ for any mortality or behavioral changes (11).

Tumor transplantation. EAC cells were obtained from the Indian Institute of Chemical Biology (Calcutta,India). The EAC cells were maintained in vivo in Swiss albino mice by intraperitoneal (i.p.) transplantation of $2 \times 10^{6}$ cells per mouse every 10 days. Ascitic fluid was drawn from the EAC tumor-bearing mice at the log phase (days 7-8 of tumor-bearing) of the tumor cells and each test animal received $0.1 \mathrm{ml}$ of i.p. tumor cell suspension containing $2 \times 10^{6}$ tumor cells.

Treatment schedule. The animals were divided into eight groups $(\mathrm{n}=12)$ and provided with food and water ad libitum. All animals in each group received EAC cells $\left(2 \times 10^{6}\right.$ cells/mouse i.p.) with the exception of group-I, which served as the normal saline control ( $5 \mathrm{ml} / \mathrm{kg}$ body weight i.p.). Group II served as the EAC control. At $24 \mathrm{~h}$ post-EAC transplantation, groups III, IV and $\mathrm{V}$ received MPBL at doses of 25,50 and $100 \mathrm{mg} / \mathrm{kg}$ i.p., respectively. Groups VI and VII also received $\mathrm{CHCl}_{3}$ (CPBL) and EtOAc (EPBL) extract at doses of $100 \mathrm{mg} / \mathrm{kg}$ i.p., whereas group VIII, serving as a positive control, received bleomycin $(0.3 \mathrm{mg} / \mathrm{kg}$ i.p) for nine consecutive days (12). At $24 \mathrm{~h}$ post-administration of the last dose, the animals were fasted for $18 \mathrm{~h}$, at which point, six animals in each group were sacrificed by cardiac puncture for the estimation of hematological and serum biochemical parameters, and to measure antitumor and liver biochemical parameters. The remainder were provided with food and water ad libitum and observed to determine if there were any changes in lifespan. The antitumor activity of the extract was measured in the EAC animals as described next.

Determination of tumor and packed cell volume. The mice were dissected and ascitic fluid was collected from the peritoneal cavity. The tumor volume was measured using a graduated centrifuge tube and the packed cell volume was determined by centrifuging the fluid at $1,000 \mathrm{xg}$ for $5 \mathrm{~min}$.

Viable and non-viable tumor cell count. The ascitic fluid was collected in a white blood cell (WBC) pipette and diluted 100 times. A drop of the diluted suspension was then placed on a Neubauer counting chamber (Celeromics, Cambridge, UK) and the cells were stained with Trypan blue ( $0.4 \%$ in normal saline). The cells that did not take up the dye were considered viable, while those that did were considered non-viable. The viable and non-viable cells were then counted using the following formula: Cell count $=$ (number of cells $\mathrm{x}$ dilution factor $) /($ area $\mathrm{x}$ thickness of liquid film).

Determination of median survival time (MST) and percentage increase in life span. The rate of mortality was monitored by recording the percentage increase in life span (\% ILS) and MST according to the following formula (13): MST in days $=$ (day of first mortality + day of last mortality) / 2 .

Estimationofhematologicalandserumbiochemicalparameters. Blood was collected to estimate the hemoglobin $(\mathrm{Hb})$ content, and red blood cell (RBC) and WBC counts (12). Differential counts of WBCs were performed from Leishmen-stained blood smears (13). Serum biochemical parameters, including serum glutamate oxaloacetate transaminase (SGOT), serum glutamate pyruvate transaminase (SGPT) (14), serum alkaline phosphatase (SALP), serum bilirubin (15) and total protein (16) levels were also estimated.

Estimation of lipid peroxidation thiobarbituric acid reactive substances (TBARS). The TBARS in the liver tissue were measured as described by Ohkawa et al (17) and expressed as $\mu$ mols of malondialdehyde (MDA)/g of liver tissues.

Estimation of reduced GSH level. The GSH level of liver tissue was determined as described by Ellman (18) and expressed as $\mu \mathrm{g} / \mathrm{g}$ of liver tissues.

Estimation of superoxide dismutase (SOD) and catalase (CAT) levels. The SOD and CAT activity in the liver tissue 


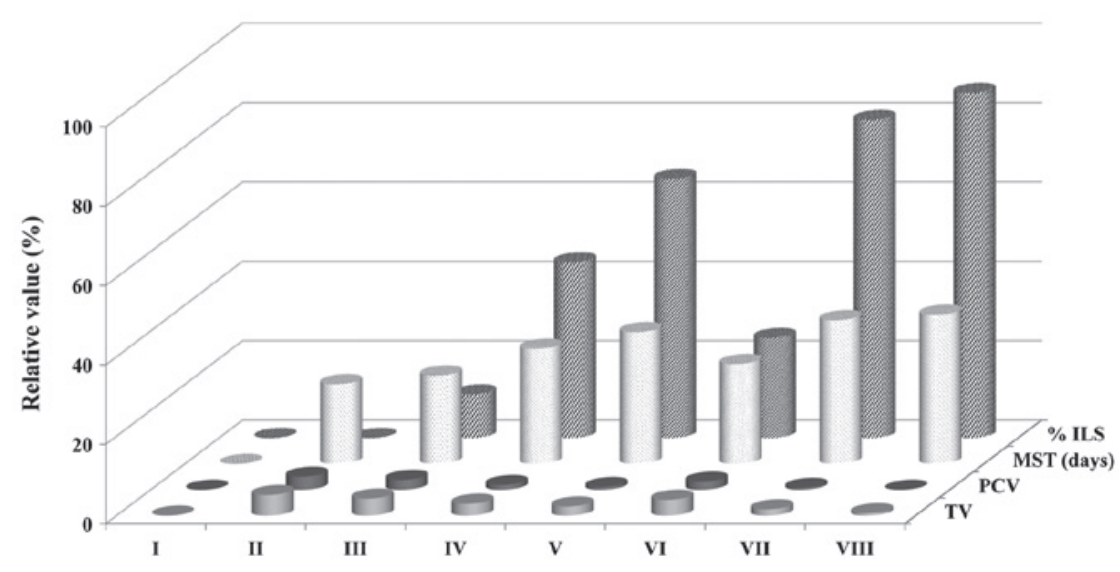

Figure 1. Effects of Piper betle extract on tumor volume, packed cell volume, MST and \% ILS in EAC-bearing mice. The data are presented as the mean \pm standard error of the mean ( $\mathrm{n}=12$ mice per group). " $\mathrm{P}<0.05 \mathrm{vs}$. EAC control group. Group I animals received normal saline ( $5 \mathrm{ml} / \mathrm{kg})$, whereas group II animals received EAC control ( $2 \times 10^{6}$ cell/mouse), group VIII received bleomycin, $0.3 \mathrm{mg} / \mathrm{kg}$ body weight, and groups III, IV and V, were treated with 25.50 and $100 \mathrm{mg} / \mathrm{kg}$ body weight (p.o.) of the MPBL, respectively. Groups VI and VII were treated with $100 \mathrm{mg} / \mathrm{kg}$ body weight (p.o.) of the CPBL and EPBL, respectively. EAC, Ehrlich ascites carcinoma; TV, total volume; PCV, packed cell volume; MST, mean survival time; \% ILS, percentage increase in life span; p.o., per os; MPBL, methanolic extract of Piper betle leaves; CPBL, chloroform; EPBL,. ethylacetate fraction.

was analyzed according to the methods described by Pari and Latha (19). The SOD activity was expressed as U/mg of liver tissue and CAT was expressed in terms of $\mu \mathrm{mol}$ of hydrogen peroxide decomposed/min/mg of liver tissue.

Statistical analysis. All values are expressed as the mean \pm standard error of the mean of three replicate experiments. Statistical analysis was performed using the SPSS version 16.0 software (SPSS Inc., Chicago, IL, USA). All in vivo data were assessed using analysis of variance followed by Dunnett's test and $\mathrm{P}<0.05$ was considered to indicate a statistically significant difference.

\section{Results}

Acute toxicity studies. Acute toxicity studies are primarily designed to develop therapeutic indices, for example, the ratio between the pharmacologically effective dose and lethal dose against the same strain and species. MPBL was safe at doses as high as 1,000 mg/kg [per os (p.o.)] body weight, causing no mortality, behavioral changes, locomotor ataxia, diarrhea or weight loss in mice during $48 \mathrm{~h}$ of observation. Additionally, food and water intake did not differ among the groups studied (data not shown).

Tumor growth and survival parameters. MPBL and EPBL at a dose of $100 \mathrm{mg} / \mathrm{kg}$ body weight significantly reduced the body weight, tumor volume, packed cell volume and viable tumor cell count (Fig. 1), however, the non-viable tumor cell count was increased compared with the EAC control group (data not shown). However, CPBL exerted no significant effects at a dose of $100 \mathrm{mg} / \mathrm{kg}$. The MST increased to $22.31 \pm 0.11$ (\% ILS, 10.99), 29.01 \pm 0.17 (\% ILS, 44.25) and $33.23 \pm 0.21$ days (\% ILS, 65.25) following the administration of MPBL at doses of 25,50 and $100 \mathrm{mg} / \mathrm{kg}$ body weight, respectively, while the EPBL and the reference drug, bleomycin, exhibited survival times of $36.23 \pm 0.31$ (\% ILS, 80.15) and $37.60 \pm 0.11$ days (\% ILS, 86.97), respectively (Fig. 1). Finally, the change in body weight (data not shown) of the animals indicated that Piper betle extracts had the potential to inhibit tumor growth.

Hematological parameters. The hematological parameters of the tumor-bearing mice were found to be significantly different compared with the normal group. The total WBC count increased $(\mathrm{P}<0.05)$ and the $\mathrm{Hb}$ content and $\mathrm{RBC}$ count decreased in the EAC control animals compared with the normal saline group. Treatment with MPBL and EPBL at a dose of $100 \mathrm{mg} / \mathrm{kg}$ body weight significantly increased the $\mathrm{Hb}$ content and RBC count towards normal levels (data not shown). Additionally, the number of neutrophils (Fig. 2A) was increased, while the numbers of lymphocytes (Fig. 2B) and monocytes (Fig. 2C) were found to decrease in the EAC control group compared with the normal group. These results indicated that treatment with varying doses of Piper betle extract could significantly change these altered parameters to near normal values (Fig. 2).

Effect on biochemical parameters. As shown in Table I, the biochemical parameters, including SGOT, SGPT, SALP and bilirubin levels, in the EAC control group were significantly upregulated compared with the normal group. Treatment with MPBL and EPBL at doses of $100 \mathrm{mg} / \mathrm{kg}$ significantly decreased the SGOT, SGPT, SALP and bilirubin levels to approximately normal levels, whereas CPBL at this dose did not produce the optimum results. The total protein level was significantly lower in the EAC control group compared with the normal group $(\mathrm{P}<0.05)$. The administration of MPBL and EPBL at a dose of $100 \mathrm{mg} / \mathrm{kg}$ body weight in the EAC-bearing mice led to a significant increase in total protein level compared with the EAC control group.

Effect on lipid peroxidation and reduced GSH. Following administration of $100 \mathrm{mg} / \mathrm{kg}$ MPBL or EPBL, or 0.3 $\mathrm{mg} / \mathrm{kg}$ bleomycin to the EAC-bearing mice, the level of lipid peroxidation decreased by $91.34 \pm 1.10,82.34 \pm 1.10$ and $167.21 \pm 1.04 \mu \mathrm{M} / \mathrm{g}$, respectively, compared with the EAC control group $(166.19 \pm 3.06 \mu \mathrm{M} / \mathrm{g}$ of wet liver tissue; $\mathrm{P}<0.05$; 
Table I. Effects of Piper betle on serum biochemical parameters in EAC-bearing mice.

\begin{tabular}{llcrcc}
\hline Group, $\mathrm{n}$ & SGOT, IU/1 & SGP, IU/1 & SALP, IU/l & Total protein, mg/dl & Bilirubin, mg/dl \\
\hline I & $38.32 \pm 1.41$ & $28.02 \pm 4.32$ & $77.91 \pm 2.24$ & $9.67 \pm 0.24$ & $0.91 \pm 0.19$ \\
II & $74.12 \pm 1.11^{\mathrm{a}}$ & $66.32 \pm 5.32^{\mathrm{a}}$ & $120.11 \pm 3.24^{\mathrm{a}}$ & $5.78 \pm 0.14^{\mathrm{a}}$ & $3.75 \pm 0.12^{\mathrm{a}}$ \\
III & $65.52 \pm 3.51^{\mathrm{b}}$ & $52.12 \pm 5.12^{\mathrm{b}}$ & $108.31 \pm 1.24^{\mathrm{b}}$ & $6.08 \pm 0.19^{\mathrm{b}}$ & $2.85 \pm 0.75^{\mathrm{b}}$ \\
VI & $42.52 \pm 5.11^{\mathrm{b}}$ & $43.32 \pm 2.32^{\mathrm{b}}$ & $97.19 \pm 5.24^{\mathrm{b}}$ & $6.18 \pm 0.34^{\mathrm{b}}$ & $2.15 \pm 0.18^{\mathrm{b}}$ \\
V & $38.12 \pm 1.01^{\mathrm{b}}$ & $39.39 \pm 1.12^{\mathrm{b}}$ & $88.10 \pm 1.27^{\mathrm{b}}$ & $6.98 \pm 1.34^{\mathrm{b}}$ & $1.75 \pm 1.18^{\mathrm{b}}$ \\
VI & $55.52 \pm 3.51^{\mathrm{b}}$ & $48.12 \pm 5.12^{\mathrm{b}}$ & $101.31 \pm 1.24^{\mathrm{b}}$ & $6.78 \pm 0.19^{\mathrm{b}}$ & $2.35 \pm 0.75^{\mathrm{b}}$ \\
VII & $34.12 \pm 1.01^{\mathrm{b}}$ & $36.39 \pm 1.12^{\mathrm{b}}$ & $83.10 \pm 1.27^{\mathrm{b}}$ & $7.78 \pm 1.34^{\mathrm{b}}$ & $1.25 \pm 1.18^{\mathrm{b}}$ \\
VIII & $35.13 \pm 1.91^{\mathrm{b}}$ & $33.01 \pm 1.31^{\mathrm{b}}$ & $73.90 \pm 1.92^{\mathrm{b}}$ & $8.38 \pm 1.14^{\mathrm{b}}$ & $0.98 \pm 1.18^{\mathrm{b}}$ \\
\hline
\end{tabular}

Data is presented as mean \pm standard error of the mean ( $\mathrm{n}=6$ mice per group). ${ }^{\mathrm{a}} \mathrm{P}<0.05$ vs. normal saline group. ${ }^{\mathrm{b}} \mathrm{P}<0.05 \mathrm{vs}$. EAC control group. Group I animals were administered normal saline $(5 \mathrm{ml} / \mathrm{kg}$ ), whereas group II received EAC control (2x106 cell/mouse), group VIII received bleomycin, $0.3 \mathrm{mg} / \mathrm{kg}$ body weight, and groups III, IV and V were treated with 25,50 and $100 \mathrm{mg} / \mathrm{kg}$ body weight (p.o.) of MPBL, respectively. Groups VI and VII were treated with $100 \mathrm{mg} / \mathrm{kg}$ body weight (p.o.) of CPBL and EPBL, respectively. EAC, Ehrlich ascites carcinoma; p.o., per os; SGOT, serum glutamate oxaloacetate transaminase; SGPT, serum glutamate pyruvate transaminase; SALP, serum alkaline phosphatase.

A

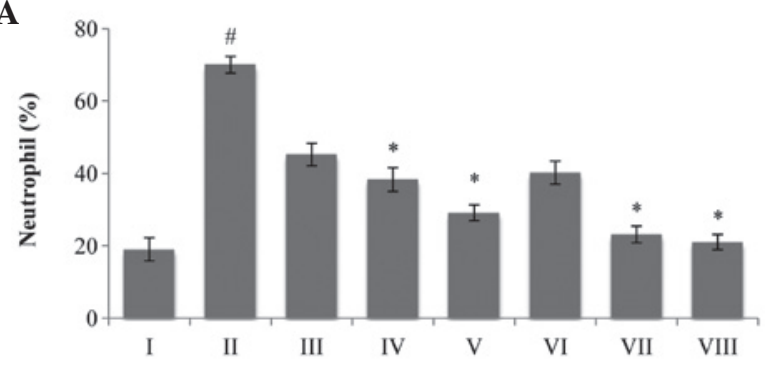

B
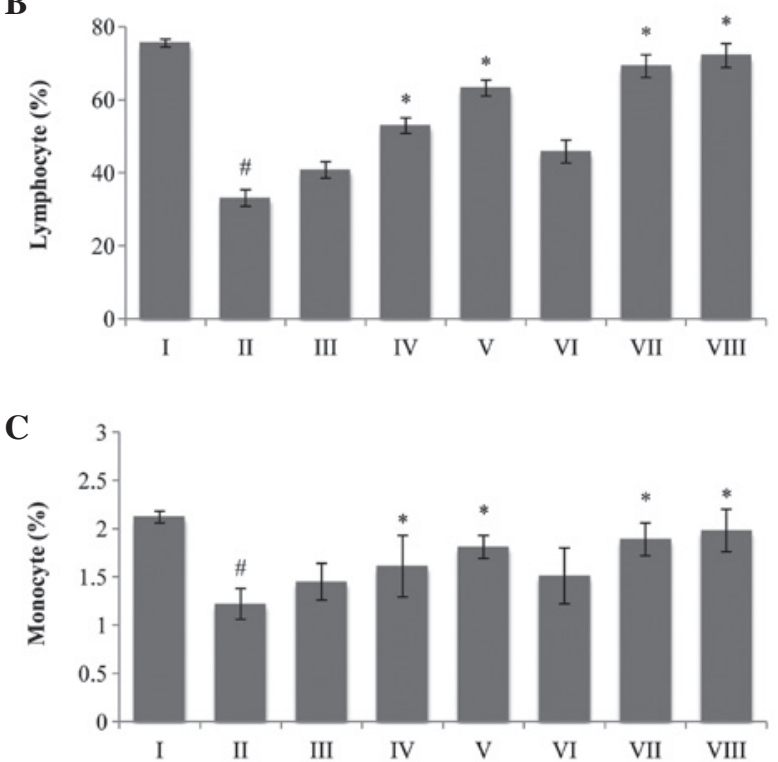

Figure 2. A classical feature of Piper betle extracts on differential count of WBCs; (A) neutrophils, (B) lymphocytes and (C) monocytes. The data are presented as the mean \pm standard error of the mean. ( $\mathrm{n}=6$ mice per group), ${ }^{\#} \mathrm{P}<0.05$ vs. normal saline group. $\mathrm{P}<0.05$ vs. EAC control group. Group I animals received normal saline $(5 \mathrm{ml} / \mathrm{kg})$, whereas group II received EAC control ( $2 \times 10^{6}$ cell/mouse), group VIII received bleomycin, $0.3 \mathrm{mg} / \mathrm{kg}$ body weight, and groups III, IV and V were treated with 25,50 and $100 \mathrm{mg} / \mathrm{kg}$ body weight (p.o.) of MPBL, respectively. Groups VI and VII were treated with $100 \mathrm{mg} / \mathrm{kg}$ body weight (p.o.) of CPBL and EPBL, respectively. EAC, Ehrlich ascites carcinoma; p.o., per os; MPBL, methanolic extract; CPBL, chloroform; EPBL, ethylacetate fraction.
Fig. 3A). Reduced GSH levels (39 $\mu \mathrm{g} / \mathrm{g}$ of wet liver tissue) were found to be significantly elevated towards the normal level upon administration of MPBL and EPBL at $100 \mathrm{mg} / \mathrm{kg}$ compared with the EAC control group ( $\mathrm{P}<0.05$; Fig. 3B).

Effect on SOD and CAT. The administration of MPBL at a dose of 25,50 and $100 \mathrm{mg} / \mathrm{kg}$ markedly increased the levels of SOD and CAT in a dose-dependent manner ( $\mathrm{P}<0.05$; Fig. 3C and D) compared with the EAC control group. By contrast, EPBL exhibited almost the same activity as standard bleomycin for the two parameters (Fig. 3).

\section{Discussion}

Initially reported as a spontaneous murine mammary adenocarcinoma, the Ehrlich tumor can be grown in the majority of mouse strains and is accepted as a transplantable tumor model to examine the antitumor effects of a number of substances (20).

In the present study, a rapid increase in ascitic tumor volume was observed in EAC tumor-bearing mice and the treatment with Piper betle extracts reduced the intraperitoneal tumor burden, thereby reducing the tumor volume, tumor weight and viable tumor cell count, while increasing the life span of the tumor-bearing mice. Therefore, it may be hypothesized that the increase in lifespan of EAC-bearing mice in response to MPBL and EPBL at $100 \mathrm{mg} / \mathrm{kg}$ may be due to a decrease in nutritional fluid volume and a delay in cell division (12). Reductions in viable cell count and increased non-viable cell count towards normal in tumor hosts indicate antitumor effects against EAC cells in mice. These results indicate that MPBL and EPBL have a direct association with tumor cells at higher doses as they absorb the anticancer drug by direct absorption in the peritoneal cavity, resulting in lysis of the cells via a direct and cytotoxic mechanism. Anemia and myelosuppression have frequently been observed in ascites carcinoma due to a deficiency in iron, in hemolytic or myelopathic conditions, resulting in a reduced number of RBCs (21). In the present 
A

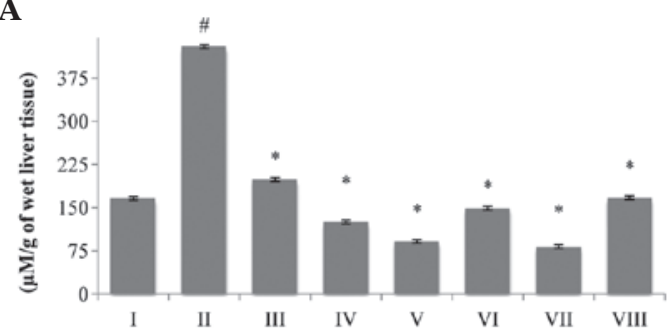

C

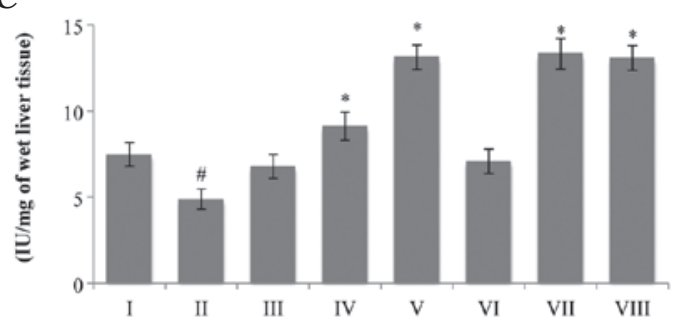

B

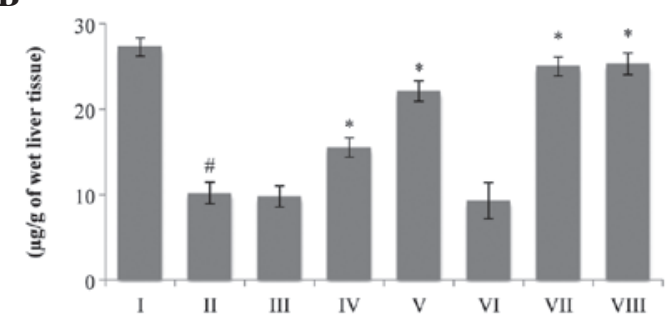

D

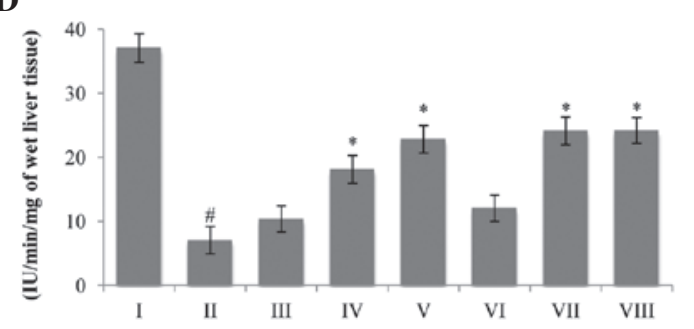

Figure 3. Effect of Piper betle on (A) lipid peroxide, (B) reduced glutathione, (C) superoxide dismutase and (D) catalase levels in EAC-bearing mice. The data are presented as the mean \pm standard error of the mean ( $\mathrm{n}=6$ mice per group), ${ }^{*} \mathrm{P}<0.05$ vs. normal saline group. $\mathrm{P}<0.05$ vs. EAC control group. Group I animals received normal saline $(5 \mathrm{ml} / \mathrm{kg})$, whereas group II received EAC control ( $2 \times 10^{6}$ cell $/$ mouse), group VIII received bleomycin, $0.3 \mathrm{mg} / \mathrm{kg}$ body weight, and groups III, IV and V were treated with 25,50 and $100 \mathrm{mg} / \mathrm{kg}$ body weight (p.o.) of MPBL, respectively. Groups VI and VII were treated with $100 \mathrm{mg} / \mathrm{kg}$ body weight (p.o.) of CPBL and EPBL, respectively. EAC, Ehrlich ascites carcinoma; p.o., per os; MPBL, methanolic extract; CPBL, chloroform; EPBL, ethylacetate fraction.

study, treatment with Piper betle extracts returned the hemoglobin content and RBC and WBC counts to almost normal levels (data not shown), indicating that the extracts exhibit hematopoietic protecting activity without myelotoxicity, the most common side-effect of cancer chemotherapy.

A preliminary phytochemical study indicated the presence of alkaloids, steroids, tannins, phenolic and flavonoid compounds and glycosides in crude extracts of Piper betle (7). A number of studies have indicated that the presence of steroids, terpenoids and phenolic compounds, including coumarins, tannins and flavonoids, exert a chemopreventive role in the progression of cancer by affecting signal transduction in cell proliferation and angiogenesis (22). Incorporation of phytosterols into the cell membrane can alter the fluidity of membranes and the activity of membrane-bound enzymes. In addition, phytosterols cause alterations in pathway signal transduction, resulting in the growth of tumors and the stimulation of apoptosis in tumor cell lines. Phytosterols have been demonstrated to enhance the in vitro proliferation of human peripheral blood lymphocytes and $\mathrm{T}$ cells, indicating the possible stimulation of the immune system (23). The marked anticancer activities of MPBL and EPBL are possibly due to the presence of alkaloids, phenolic compounds, flavonoids and terpenoids, and their synergistic effects.

ROS exhibit multiple functions and are involved in tumor initiation and progression (24). MDA, a free oxygen radical product formed during oxidative degeneration of cancerous tissues (25) and as the end product of lipid peroxidation, is a biomarker of oxidative stress that has been reported to be exhibited at higher levels in cancer tissues than in non-diseased organs (26). The results of the present study indicated that the TBARS levels in the cancerous tissues were higher than those in the normal tissues (Fig. 3). Treatment with EPBL inhibited hepatic lipid peroxidation, as indicated by the reduction of MDA levels toward normal levels, emphasizing the reduction in free radical production and the subsequent decrease in damage to the cell membrane and MDA production in the tumor-bearing mice.

Depleted endogenous antioxidant enzyme levels with enhanced free radical generation have been well documented in carcinogenesis (27). Numerous tumor cells with pro-oxidant status promote oxidative stress, which increases the surviving potential of the cancer cells by inducing mutations, activating redox signaling and stimulating pro-survival factors, such as nuclear factor- $\mathrm{\kappa B}$ and activator protein-1 (28). GSH, which strongly inhibits the neoplastic process, is important in the endogenous antioxidant system. This compound acts mainly as a reducing agent and detoxifies hydrogen peroxide when GSH peroxidase is present (29). In the current study, the GSH levels in the experimental mice were found to be significantly lower than those in the EAC control mice (Fig. 3). These results revealed that the antitumor activity of MPBL and EPBL was accompanied by the enhancement of non-enzymatic antioxidant protection.

It is well-known that cells exhibit enzymatic antioxidant mechanisms, such as the generation of SOD and CAT, which are involved in the elimination of free radicals (30). SOD and CAT are involved in the scavenging of superoxide and hydrogen peroxide. In a previous study, decreased levels of SOD activity were detected in EAC-bearing mice in response to the loss of $\mathrm{Mn}^{2+}-\mathrm{SOD}$ activity and mitochondria in EAC cells, resulting in a decrease in the amount of total SOD activity in the liver (31). The inhibition of SOD and CAT activity as a consequence of tumor growth has also been reported (32). Similar findings were observed in the present study on EAC-bearing mice. The administration of MPBL and EPBL at higher doses increased the SOD and CAT levels towards normal levels.

Plant-derived extracts with antioxidant potential have demonstrated cytotoxicity against tumor cells and antitumor activity in experimental animals (33). The cytotoxic and 
antitumor activity of plant-derived products occurs either through the induction of apoptosis or the inhibition of neovascularization (34). In the present study, higher doses of MPBL and EPBL dramatically reduced tumor growth and the viability of the tumor cells, and normalized the hematological and serum biochemical profiles, increasing the life span compared with the EAC control mice. MPBL and EPBL treatment improved the endogenous non-enzymatic and enzymatic antioxidant systems (Fig. 3). The decrease in lipid peroxidation and the elevation of GSH, SOD and CAT levels in the MPBLand EPBL-treated mice indicated the potential of Piper betle extract as an inhibitor of EAC-induced intracellular oxidative stress.

In conclusion, Piper betle leaf extracts exhibited marked antitumor activity against EAC in the mice of the present study, possibly by modulating lipid peroxidation and augmenting endogenous antioxidant defense systems. Future studies are required to investigate the isolation and characterization of lead compounds responsible for the aforementioned activity of this plant.

\section{Acknowledgements}

The authors would like to thank Professor M. Ekramul Haque (Department of Pharmacy, Rajshahi University, Rajshahi, Bangladesh) for providing the EAC cells.

\section{References}

1. Rajkumar V, Guha G and Kumar RA: Antioxidant and anti-neoplastic activities of Picrorhiza kurroa extracts. Food Chem Toxicol 49: 363-369, 2011.

2. Suja KP, Jayalekshmy A and Arumughan C: Free radical scavenging behavior of antioxidant compounds of sesame (Sesamum indicum L.) in DPPH* system. J Agric Food Chem 52 912-915, 2004

3. Meyskens FL Jr and Szabo E: Diet and cancer: the disconnect between epidemiology and randomized clinical trials. Cancer Epidemiol Biomarkers Prev 14: 1366-1369, 2005.

4. Murukami A, Ali AM, Mat-Salleh K, Koshimizu K and Ohigashi $\mathrm{H}$ : Screening for the in vitro anti-tumor-promoting activities of edible plants from Malaysia. Biosci Biotechnol Biochem 64: 9-16, 2000.

5. Santhanam G and Nagarajan S: Wound healing activity of Curcuma aromatica and Piper betle. Fitoterapia 61: 458-459, 1990.

6. Saravanan R, Prakasam A, Ramesh B and Pugalendi KV: Influence of Piper betle on hepatic marker enzymes and tissue antioxidant status in ethanol-treated Wistar rats. J Med Food 5: 197-204, 2002

7. Choudhary D and Kale RK: Antioxidant and non-toxic properties of Piper betle leaf extract: in vitro and in vivo studies. Phytother Res 16: 461-466, 2002.

8. Bhide SV, Zariwala MB, Amonlar AJ and Azuine MA: Chemo-preventive efficacy of betel leaf extract against benzo[a]pyrene induced fore-stomach tumors in mice. J Ethnopharmacol. 34: 207-213, 1991.

9. Garg SC and Jain R: Biological activity of the essential oil of Piper betle L. J Essent oil Res 23: 601-606, 1992.

10. Singh M, Shakya S, Soni VK, et al: The n-hexane and chloroform fractions of Piper betle L. trigger different arms of immune responses in BALB/c mice and exhibit antifilarial activity against human lymphatic filarid Brugia malayi. Int Immunopharmacol 9: 716-728, 2009.

11. Zahan R, Alam MB, Islam MS, et al: Anticancer Activity of Alangium salviifolium flower in Ehrlich ascites carcinoma bearing mice. Int J Cancer Res 7: 254-262, 2011.
12. Sur P, Bag SP and Khanam JA: Choroacetohydroxamic acid as antitumor agent against Ehrlich ascites carcinoma in mice. Neoplasma 44: 197-201, 1997.

13. Gupta M, Mazumder UK, Kumar RS, et al: Antitumor activity and antioxidant status of Caesalpinia bonducella against Ehrlich ascites carcinoma in Swiss albino mice. J Pharmacol Sci 94: 177-184, 2004.

14. Bergmeyer HU, Scelibe P and Wahlefeld AW: Optimization of methods for aspirate aminotransferase and alanine aminotransferase. Clin Chem 24: 58-73, 1978.

15. Malloy HT and Evelyn KA: The determination of bilirubin with the photometric colorimeter. J Biol Chem 119: 481-490, 1937.

16. Lowry OH, Rosebrough NJ, Farr AL and Randall RJ: Protein measurement with the Folin-phenol reagent. J Biol Chem 193: 265-275, 1951 .

17. Ohkawa H, Onishi N and Yagi K: Assay for lipid peroxidation in animal tissue by thiobarbituric acid reaction. Anal Biochem 95: 351-358, 1979.

18. Ellman GL: Tissue sulfhydryl groups. Arch Biochem Biophys 82: 70-77, 1959.

19. Pari L and Latha M: Protective role of Scoparia dulcis plant extract on brain antioxidant status and lipid peroxidation in STZ diabetic male Wistar rats. BMC Compliment Alternat Med 4: 16, 2004.

20. Segura JA, Barbero LG and Márquez J: Ehrlich ascites tumor unbalances splenic cell populations and reduced responsiveness of T cells to Staphylococcus aureus enterotoxin B stimulation. Immunomol Lett 74: 111-115, 2000.

21. Opare Kennedy D, Kojima A, Hasuma T, et al: Growth inhibitory effects of green tea extract and (-)-epigallocatechin in Ehrlich ascites tumor cells involves a cellular thiol-dependent activation of mitogenic-activated protein kinases. Chem Biol Interac 134, 113-133, 2001.

22. Blois MS: Antioxidant determination by the use of a stable free radical. Nature 181: 1199-1200, 1958.

23. Jones PJ and AbuMweis SS: Phytosterols as functional food ingredients: linkages to cardiovascular disease and cancer. Curr Opin Clin Nutr Metabol Care 12: 147-151, 2009.

24. Valko M, Leibfritz D, Moncol J,et al: Free radicals and antioxidants in normal physiological functions and human disease. Int J Biochem Cell Biol 39: 44-84, 2007.

25. Valenzuela A: The biological significance of malondialdehyde determination in the assessment of tissue oxidative stress. Life Sci 48: 301-309, 1991

26. Yagi K: Lipid peroxides and human diseases. Chem Phys Lipids 45: 337-351, 1987.

27. Szatrowski TP and Nathan CF: Production of large amounts of hydrogen peroxide by human tumor cells. Cancer Res 51: 794-798, 1991

28. Seeram NP, Adams LS, Henning SM, et al: In vitro antiproliferative, apoptotic and antioxidant activities of punicalagin, ellagic acid and a total pomegranate tannin extract are enhanced in combination with other polyphenols as found in pomegranate juice. J Nutr Biochem 16: 360-367, 2005.

29. Haldar PK, Kar B, Bala A, et al: Antitumor activity of Sansevieria roxburghiana rhizome against Ehrlich ascites carcinoma in mice. Pharm Biol 48: 1337-1343, 2010.

30. Rushmore TH and Picket CB: Glutathione S-transferases, structure, regulation and therapeutic implication. J Biol Chem 268: 11475-11478, 1993.

31. Marklund SL, Westman NG, Lundgren E and Roos G: Copperand zinc-containing superoxide dismutase, manganese containing superoxide dismutase, catalase, and glutathione peroxidase in normal and neoplastic human cell lines and normal human tissues. Cancer Res 42: 1955-1961, 1982.

32. Sun Y, Oberley LW, Elwell JH and Sierra-Rivera E: Antioxidant enzyme activities in normal and transformed mice liver cells. Int J Cancer 44: 1028-1033, 1989.

33. Ruby AJ, Kuttan G, Babu KD, Rajasekharan KN and Kuttan R: Anti-tumour and antioxidant activity of natural curcuminoids. Cancer Lett 94: 79-83, 1995.

34. Rakshit S, Mandal L, Pal BC, et al: Involvement of ROS in

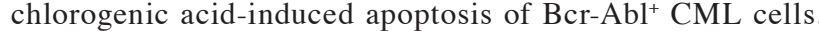
Biochem Pharmacol 80: 1662-1675, 2010. 